\title{
Urea Poisoning in a Non-Descript Goat: A Case Report
}

\author{
J.J. Parmar*, Neha Rao, D.B. Sadhu, A.I. Shah and D.M. Patel \\ Veterinary Clinical Complex, College of Veterinary Science and Animal Husbandry, Anand \\ Agricultural University, Anand-188001, Gujarat, India \\ *Corresponding author
}

\section{Keywords}

Areca nut, UHPLC,

Redox titration,

Vitamin $\mathrm{B}_{6}$,

Vitamin C

Article Info

Accepted:

12 September 2018

Available Online:

10 October 2018

\section{A B S T R A C T}

A seven year old female goat weighing $33 \mathrm{~kg}$ was presented with history of ingestion of unknown of Urea fertilizer before half an hour. Clinically animal was active and physiological parameters like rectal temperature and respiration rates were within normal range. Tachycardia and mild bloat with reduced rumen motility was also noted. The goat was given Inj. Normal Saline@25m1/kg body weight along with Inj. Dexamethasone@ $2 \mathrm{mg} / \mathrm{kg}$, Inj. Atropine Sulphate@ $0.02 \mathrm{mg} / \mathrm{kg}$ body weight intravenous. Inj. Enrofloxacin@2.5mg/kg body weight intramuscular was given. Activated Charcoal $30 \mathrm{ml}$ was given orally. Next day animal was presented without signs of bloat and all the physiological parameters were within normal range.

\section{Introduction}

Agricultural fertilizers containing ammonium nitrate and urea cause toxicological hazards to livestock after ingestion.

Due to rapid production of excessive quantities of ammonia resulting in hyperammonemia (Campagnolo et al., 2005). Urea is used as a source of non-protein nitrogen feed supplement to synthesize protein by rumen microflora to ammonia but when more urea is consumed than free ammonia circulate in the blood leading to poisoning which can occur rapidly from a few minutes to four hours after urea consumption (Parkes et al., 2011).

This paper presents case report of urea poisoning in a non-descript goat. 


\section{Case history and Observations}

A seven year old female goat weighing $33 \mathrm{~kg}$ was presented under Emergency at Veterinary Clinical Complex, Veterinary College, Anand with history of ingestion of unknown of Urea fertilizer before half an hour. Clinically animal was active and physiological parameters like rectal temperature and respiration rates were within normal range. Tachycardia and mild bloat with reduced rumen motility was also noted.

\section{Treatment and Discussion}

The goat was given Inj. Normal Saline@ $25 \mathrm{ml} / \mathrm{kg}$ body weight along with Inj. Dexamethasone@ 2mg/kg, Inj. Atropine Sulphate@ $0.02 \mathrm{mg} / \mathrm{kg}$ body weight intravenous. Inj. Enrofloxacin@ 2.5mg/kg body weight intramuscular was given. Activated Charcoal $30 \mathrm{ml}$ was given orally. Next day animal was presented without signs of bloat and all the physiological parameters were within normal range. The rumen microbiotas have the ability to hydrolyze urea into ammonium (NH4+) and ammoniac (NH3) to synthesize their own protein (Aytekin et al., 2011). Edjtehadi et al., (1978) fed urea to sheeps and found increased respiration and pulse rates along with reduced rumen motility with bloat and the sheeps died within 60 to 165 min after receiving urea @ 0.5 to $0.75 \mathrm{~g} / \mathrm{kg}$ body weight. In our case animal had tachycardia and reduced rumen motility and mild bloat without any other symptoms indicating low dose ingestion of urea than the fatal dose. Sharma et al., (2017) reported a case of acute urea toxicity in non- descript pregnant buffalo treated for three days with Inj. Normal Saline along with other medications and oral medicines for seven days while in our case animal showed improvement at very next day after the treatment. Nitrogen based farm fertilizers are harmful to ruminants upon ingestion in higher amounts so animal owners and farmers need to take extra care to reduce accidental ingestion in animal body and this can reduce toxicity in animals.

\section{References}

Aytekin, I., Onmaz, A.C., Ulucan, A., and Alp, H. (2011). Effects of accidental ammonium sulphate poisoning on antioxidant / oxidant status in lambs. Revue Med. Vet., 162 (7): 346-351.

Campagnolo, E. R., Steve Kaste, M. S. and Banerjee, M. (2002). Accidental ammonia exposure to country fair show livestock due to contaminated drinking water. Vet Human Toxicol, 44(5): 282285.

Edjtehadi, M., Szabuniewicz, M. and Emmanuel, B. (1978). Acute urea toxicity in sheep. Can. J. comp. Med., 42:63-68.

Parkes, H., Shilton, C., Darwin, Eccles, J. and Katherine (2011). Urea poisoning in cattle. Northern Territory Government: 1-3. www.nt.gov.au/d.

Sharma, S. K., Monika Joshi, Kuldeep Kumar and Parmjeet (2017). Acute urea poisoning in buffaloes: Case Study. Research \& Reviews: Journal of Veterinary Sciences, 3(1):1-3.

\section{How to cite this article:}

Gurumurthy, B.R. and Naik, M.K. 2018. Techniques for Determination of Vitamin B 6 , Vitamin $\mathrm{C}$ and Variability in Areca Nut (Areca catechu) Samples of Karnataka, India. Int.J.Curr.Microbiol.App.Sci. 7(10): 1448-1449. doi: https://doi.org/10.20546/ijcmas.2018.710.161 